\title{
Peningkatan Keterampilan Membaca Teks Klasifikasi Menggunakan Metode SQ3R dengan Media Gambar
}

\author{
Trisman Harefa \\ (Prodi Pendidikan Bahasa Idonesia, FPBS, IKIP Gunungsitoli, Sumatera Utara) \\ * Corresponding-Author. Email: trisman_harefa@ymail.com
}

Receive: $13 / 02 / 2021$

Accepted: 25/02/2021

Published: 01/03/2021

\begin{abstract}
Abstrak
Pembelajaran membaca teks klasifikasi peserta didik kelas X-MIPA SMA Negeri 1 Gunungsitoli Idanoi belum terlaksana secara optimal karena pembelajaran yang dilakukan belum mampu memotivasi peserta didik dengan baik. Perlu metode dan media pembelajaran yang lebih efektif dan mampu memotivasi peserta didik. Subjek penelitian ini adalah keterampilan membaca peserta didik kelas X SMA Negeri 1 Gunungsitoli Idanoi. Adapun sumber data penelitian ini adalah kelas X-MIPA SMA Negeri 1 Gunungsitoli Idanoi. Jenis penelitian yang digunakan adalah penelitian tindakan kelas. Hasil penelitian menunjukkan peningkatan secara signifikan. Rata-rata nilai keterampilan peserta didik, keterampilan membaca teks klasifikasi diikuti perubahan sikap religius dan sosial ke arah positif yang lebih baik. Respon peserta didik terhadap pembelajaran juga sangatlah baik.
\end{abstract}

Kata kunci: membaca teks, metode SQ3R, media gambar

\begin{abstract}
Learning to read the classification text of students of class X-MIPA SMA Negeri 1 Gunungsitoli Idanoi has not been implemented optimally because the learning carried out has not motivated learners well. It needs more effective learning methods and media and can motivate learners. The subject of this study is the reading skills of students of class X SMA Negeri 1 Gunungsitoli Idanoi. The source of this research data is class X-MIPA SMA Negeri 1 Gunungsitoli Idanoi. The type of research used is class action research. The results showed a significant improvement. The average value of learners' skills and classification text reading skills followed changes in religious and social attitudes positively. The response of students to learning is also excellent.
\end{abstract}

Keywords: reading text, $S Q 3 R$ method, image media

\section{Pendahuluan}

Membaca merupakan interaksi antara pembaca dan penulis. Interaksi tersebut tidak langsung, namun bersifat komunikatif. Komunikasi antara pembaca dan penulis akan semakin baik jika pembaca mempunyai kemampuan yang lebih baik (Armitasari, 2015; Dalman, 2014). Pembaca hanya dapat berkomunikasi dengan karya tulis yang digunakan oleh pengarang sebagai media untuk menyampaikan gagasan, perasaan, dan pengalamannya. Dengan demikian pembaca harus mampu menyusun pengertianpengertian yang tertuang dalam kalimatkalimat yang disajikan oleh pengarang sesuai dengan konsep yang terdapat pada diri pembaca.

Salah satu faktor yang penting dalam kehidupan masyarakat modern. Kemampuan membaca menjadi kebutuhan karena penyebaran informasi dan pesanpesan dalam dunia modern ini disajikan dalam bentuk tertulis, dan hanya dapat 
diperoleh melalui membaca. Apabila seseorang tidak mampu membaca sehingga tidak memahami suatu petunjuk atau pengumuman yang tertulis, maka orang tersebut akan ketinggalan, salah jalan, atau tidak dapat menyesuaikan diri dengan lingkungannya (Adipta, 2016; Zuhri, 2012; Ilmi, dkk., 2017).

Berdasarkan data yang peneliti temukan melalui wawancara terhadap guru mata pelajaran bahasa Indonesia kelas $\mathrm{X}$ di SMA Negeri 1 Gunungsitoli Idanoi, penguasaan keterampilan membaca teks klasifikasi peserta didik kelas X-MIPA SMA Negeri 1 Gunungsitoli Idanoi masih belum optimal. Terbukti dari 34 peserta didik, hanya 12 peserta didik yang mampu mencapai kriteria ketuntasan minimal yakni 75. Hal ini menunjukkan bahwa kompetensi pengetahuan dan keterampilan peserta didik dalam membaca teks klasifikasi belum optimal.

Hasil pengamatan guru terhadap sikap peserta didik juga belum menunjukkan karakter religious dan sosial secara maksimal. Penilaian guru terhadap pengetahuan dan keterampilan membaca teks klasifikasi peserta didik juga belum sepenuhnya memuaskan. Hanya 11 dari 34 peserta didik yang mampu mencapai ketuntasan minimal. Peserta didik yang belum mencapai kriteria minimal umumnya memiliki beberapa permasalahan terkait pengetahuan dan keterampilan dalam membaca.

Permasalahan tersebut antara lain; 1) peserta didik kurang terampil dalam membaca sebuah teks, 2) peserta didik masih kurang memerhatikan pokok-pokok bacaan, 3) peserta didik cepat merasa jenuh dengan teks bacaan yang panjang, dan 4) peserta didik masih kurang teliti dalam membaca, 5) setelah membaca, peserta didik kesulitan dalam menyimpulkan bacaan, dan 6) pembelajaran dirasakan monoton dan membosankan oleh peserta didik karena metode serta media pembelajaran kurang digunakan secara optimal.
Permasalahan-permasalaan tersebut menjadi tantangan bagi guru mata pelajaran bahasa Indonesia untuk menciptakan suasana baru dalam pembelajaran membaca. Suasana dan cara baru itu diharapkan mampu meningkatkan semangat belajar dan keterampilan membaca siswa. Hal ini memberi indikasi bahwa metode dalam membaca menjadi sangat penting dalam kegiatan pembelajaran di kelas $\mathrm{X}$ SMA Negeri 1 Gunungsitoli Idanoi. Metode ini berfungsi mengangkat semangat peserta didik dalam pembelajaran membaca. Selain itu, metode dalam membaca diharapkan mampu mengefektifkan pembelajaran keterampilan membaca di dalam kelas.

Melihat permasalahan tersebut, peneliti menawarkan solusi berupa penggunaan metode SQ3R dan media gambar dalam pembelajaran membaca. Salah satu metode dalam keterampilan membaca adalah metode SQ3R. Metode ini mengarahkan pembaca melakukan Survey, Question, Reading, Recite, dan Review dalam kegiatan membaca. Tahapan-tahapan tersebut akan memudahkan pembaca dalam menemukan pokok bacaan dan menyimpulkan isi bacaan yang telah dibaca (Sobri, 2017; Usman, 2015).

Metode SQ3R menerapkan cara membaca menemukan pokok-pokok penting dalam bacaan. Kemudian pembaca membuat catatan-catatan penting berdasarkan sudut pandang pribadi. Berdasarkan beberapa teori mengenai metode SQ3R di atas, hal penting dalam metode ini adalah keselarasan dan kesinambungan setiap tahapnya. Artinya, tahap dalam metode ini tidak dapat digunakan secara terpisah maupun bebas (Agustina \& Hariyadi, 2018).

Setiap tahapan dalam metode ini harus diterapkan secara terstruktur dan terpola agar tujuan membaca dapat tercapai dengan baik. Melihat manfaat dan keefektifan metode SQ3R dalam membaca, peneliti akan menggunakan metode ini sebagai upaya peningkatan keterampilan membaca peserta didik pada jenjang SMA. 
Dengan metode ini, peneliti berharap keterampilan membaca peserta didik dalam penelitian ini akan meningkat. Fakta di lapangan juga menunjukkan bahwa media pembelajaran yang digunakan dalam pembelajaran membaca kurang optimal. Hal ini menyebabkan peserta didik sering dihinggapi rasa jenuh dalam kegiatan pembelajaran. Selain metode SQ3R, peserta didik akan dimudahkan dengan media gambar untuk mengulas kembali bacaan. Isi tayangan gambar disesuaikan dengan teks yang dibaca oleh peserta didik. Jadi, setelah peserta didik membaca sebuah bacaan dengan langkah-langkah sesuai metode SQ3R, mereka mengulas kembali isi bacaan dengan acuan sebuah gambar (Karmawan, 2016).

Gambar adalah segala sesuatu yang diwujudkan secara visual dalam bentuk dua dimensi sebagai curahan perasaan atau pikiran. Hal ini menunjukkan bahwa gambar dapat mewakili suatu ide, termasuk curahan perasaan ataupun pikiran. Pendapat ini menunjukkan bahwa dengan gambar ide-ide pengajar dalam pembelajaran yang sulit untuk dijelaskan dengan ceramah akan lebih mudah jika disajikan dengan gambar. Sebab tidak semua hal dapat dideskripsikan secara gamblang melalui penjelasan lisan (Rahman, 2014).

Gambar atau foto termasuk dalam media grafis. Di antara media pendidikan, gambar atau foto merupakan media yang paling umum dipakai. Ia merupakan bahasa yang umum dan dapat dimengerti serta dinikmati di mana-mana. Sebab, seseorang dapat dengan mudah menemukan dan menyajikan gambar sebagai media pembelajaran. Gambar juga mampu mendeskripsikan dengan baik dan nyata sebuah ide atau suatu hal pada imajinasi seseorang (Adipta, dkk., 2016).

Penelitian ini dilakukan dengan mendeskripsikan proses pembelajaran. Penelitian ini juga mengungkapkan hasil peningkatan pengetahuan dan keterampilan peserta didik dalam membaca teks klasifikasi. Selain itu, penelitian ini juga mendeskripsikan perubahan sikap religius dan sosial peserta didik dalam mengikuti pembelajaran membaca teks klasifikasi menggunakan metode SQ3R dengan media gambar.

\section{Metode}

Penelitian ini menggunakan desain penelitian tindakan kelas. Penelitian tindakan kelas ialah salah satu upaya guru atau praktisi dalam bentuk berbagai kegiatan yang dilakukan untuk memperbaiki dan atau meingkatkan mutu pembelajaran di kelas (Anwar, 2012). Penelitian tindakan kelas merupakan kegiatan yang langsung berhubungan dengan tugas guru di lapangan (Arikunto, dkk., 2015). Singkatnya, PTK merupakan penelitian praktis yang dilakukan di kelas dan bertujuan untuk memperbaiki praktik pembelajaran yang ada.

Subjek penelitian ini adalah keterampilan membaca peserta didik kelas X SMA Negeri 1 Gunungsitoli Idanoi. Adapun sumber data penelitian ini adalah kelas X-MIPA SMA Negeri 1 Gunungsitoli Idanoi. Peneliti berkolaborasi dengan guru dalam menentukan metode membaca dan media pembelajaran untuk meningkatkan keterampilan membaca peserta didik kelas X-MIPA SMA Negeri 1 Gunungsitoli Idanoi.

Data dalam penelitian ini berupa data kuantitatif dan data kualitatif. Data kuantitatif berupa hasil tes pengetahuan dan keterampilan peserta didik dalam membaca teks klasifikasi. Adapun data kualitatif diperoleh dari hasil observasi, jurnal, wawancara, dan dokumentasi. Analisis data juga dilakukan secara kuantitatif dan kualitatif. Data hasil tes pengetahuan dan keterampilan dianalisis dengan teknik analisis kuantitatif. Sementara hasil observasi, jurnal, wawancara, dan dokumentasi dianalisis secara kualitatif..

\section{Hasil dan Pembahasan}

Setelah dilakukan penelitian keterampilan membaca teks klasifikasi menggunakan metode SQ3R dengan media gambar, keberlangsungan proses 
pembelajaran membaca teks klasifikasi pada peserta didik kelas X-MIPA SMA Negeri 1 Gunungsitoli Idanoi semakin baik. Pada siklus I aspek pengamatan proses mengalami masih belum maksimal. Namun, pada siklus II setiap aspek pengamatan proses mengalami peningkatan. Aspek keantusiasan peserta didik dalam proses pembelajaran mengalami peningkatan 19\% dari siklus I ke siklus II. Aspek antusias peserta didik dalam membaca menggunakan metode SQ3R persentase ketuntasannya mengalami peningkatan $11 \%$ dari siklus I. Persentase ketuntasan keefektifan dan keantusiasan peserta didik menggunakan media gambar dalam menyimpulkan bacaan persentase ketuntasannya mengalami peningkatan 15\% pada siklus II. Adapun aspek keaktifan dan keantusiasan peserta didik dalam proses refleksi pembelajaran meningkat 33\% pada siklus II. Rata-rata peningkatan persentase ketuntasan hasil pengamatan proses pembelajaran dari siklus I ke siklus II meningkat $19,5 \%$. Berikut tabel peningkatan persentase ketuntasan hasil pengamatan proses pembelajaran.

Tabel 1. Peningkatan Persentase Ketuntasan Hasil Pengamatan Proses Pembelajaran Siklus I ke Siklus II

\begin{tabular}{|c|c|c|c|c|}
\hline No & Aspek & Siklus I & Siklus II & Peningkatan \\
\hline 1 & $\begin{array}{l}\text { Antusias peserta didik } \\
\text { dalam proses } \\
\text { pembelajaran }\end{array}$ & $73 \%$ & $92 \%$ & $19 \%$ \\
\hline 2 & $\begin{array}{l}\text { Antusias peserta didik } \\
\text { dalam membaca } \\
\text { menggunakan } \\
\text { metode SQ3R }\end{array}$ & $88 \%$ & $99 \%$ & $11 \%$ \\
\hline 3 & $\begin{array}{lr}\text { Keefektifan } & \text { dan } \\
\text { antusias peserta didik } \\
\text { menggunakan media } \\
\text { gambar } & \text { dalam } \\
\text { menyimpulkan } & \\
\text { bacaan } & \\
\end{array}$ & $85 \%$ & $100 \%$ & $15 \%$ \\
\hline 4 & $\begin{array}{lr}\text { Keefektifan } & \text { dan } \\
\text { antusias peserta didik } \\
\text { dalam refleksi } \\
\text { pembelajaran }\end{array}$ & $67 \%$ & $100 \%$ & $33 \%$ \\
\hline & Rata-rata & $78,25 \%$ & $97,75 \%$ & $19,5 \%$ \\
\hline
\end{tabular}

Sikap religius peserta didik kelas $\mathrm{X}$ MIPA SMA Negeri 1 Gunungsitoli Idanoi mengalami peningkatan setelah mengikuti pembelajaran membaca teks klasifikasi menggunakan metode SQ3R dengan media gambar. Pada siklus I, persentase ketuntasan sikap religius peserta didik mencapai $81 \%$. Sementara pada siklus I, persentase ketuntasan sikap religius peserta didik meningkat menjadi 90\%. Dengan demikian, sikap religius peserta didik mengalami peningkatan 9\% dari siklus I ke siklus II. Berikut tabel yang mendeskripsikan peningkatan perubahan sikap religius peserta didik.

Tabel 2 Peningkatan Perubahan Sikap Religius pada Siklus I dan Siklus II

\begin{tabular}{|c|c|c|c|c|}
\hline No & Aspek & Siklus I & Siklus II & Peningkatan \\
\hline 1 & $\begin{array}{l}\text { Sikap religious } \\
\text { mensyukuri nikmat } \\
\text { Tuhan Yang Maha } \\
\text { Esa }\end{array}$ & $81 \%$ & $90 \%$ & $9 \%$ \\
\hline
\end{tabular}

Sikap sosial peserta didik kelas XMIPA SMA Negeri 1 Gunungsitoli Idanoi mengalami peningkatan setelah mengikuti pembelajaran membaca teks klasifikasi menggunakan metode SQ3R dengan media gambar. Sikap jujur, tanggung jawab, toleransi, santun, percaya diri, kritis dan semangat mengalami peningkatan dari siklus I ke siklus II. Berikut tabel yang mendeskripsikan hasil peningkatan perubahan sikap sosial peserta didik dalam pembelajaran membaca teks klasifikasi menggunakan metode SQ3R dengan media gambar.

Tabel 3 Peningkatan Perubahan Sikap Sosial pada Siklus I dan Siklus II 


\begin{tabular}{|c|l|c|c|}
\hline No & Aspek Observasi & Siklus I & Siklus II \\
\hline 1 & Jujur & $74 \%$ & $92 \%$ \\
\hline 2 & Tanggungjawab & $89 \%$ & $95 \%$ \\
\hline 3 & Toleransi & $81 \%$ & $90 \%$ \\
\hline 4 & Santun & $65 \%$ & $90 \%$ \\
\hline 5 & Percaya diri & $17 \%$ & $95 \%$ \\
\hline 6 & Kritis & $21 \%$ & $90 \%$ \\
\hline 7 & Semangat & $88 \%$ & $95 \%$ \\
\hline
\end{tabular}

Pengetahuan membaca teks

klasifikasi peserta didik kelas X-MIPA SMA Negeri 1 Gunungsitoli Idanoi mengalami peningkatan dan dapat memenuhi target ketuntasan yang diharapkan. Pada siklus I, nilai rata-rata tes pengetahuan mencapai 90 dengan ketuntasan $87 \%$. Sementara pada siklus II nilai rata-rata meningkat menjadi 98 dengan ketuntasan 96\%. Dengan demikian, terjadi peningkatan dalam penilaian pengetahuan membaca teks klasifikasi peserta didik dari siklus I ke siklus II. Hasil tes pengetahuan dapat dilihat pada tabel berikut.

Tabel 4 Hasil Tes Pengetahuan Membaca Teks Klasifikasi Siklus I dan II

\begin{tabular}{|c|c|c|c|c|c|c|c|}
\hline \multirow{2}{*}{ No } & \multirow{2}{*}{ Skor } & \multicolumn{3}{|c|}{ Siklus I } & \multicolumn{3}{|c|}{ Silklus II } \\
\hline & & $\mathbf{F}$ & $\mathbf{P}$ & B & $\mathbf{F}$ & $\mathbf{P}$ & B \\
\hline 1 & 100 & 18 & $78 \%$ & 1800 & 21 & $87,5 \%$ & 2200 \\
\hline 2 & 80 & 2 & $9 \%$ & 220 & 2 & $9 \%$ & 150 \\
\hline 3 & 60 & 3 & $14 \%$ & 60 & 1 & $4 \%$ & 0 \\
\hline 4 & 40 & 0 & $0 \%$ & 0 & 0 & $0 \%$ & 0 \\
\hline 5 & $0-20$ & 0 & $0 \%$ & 0 & 0 & $0 \%$ & 0 \\
\hline \multicolumn{2}{|c|}{ Jumlah } & 23 & $100 \%$ & 2080 & 24 & $100 \%$ & 2350 \\
\hline \multicolumn{2}{|c|}{ Rerata } & \multicolumn{3}{|c|}{$\frac{2180}{23}=90$} & \multicolumn{3}{|c|}{$\frac{2350}{24}=98$} \\
\hline \multicolumn{2}{|c|}{ Ketuntasan } & \multicolumn{3}{|c|}{$\frac{20}{23} \times 100 \%=87 \%$} & \multicolumn{3}{|c|}{$\frac{23}{24} \times 100 \%=96 \%$} \\
\hline \multicolumn{2}{|c|}{ Ket } & \multicolumn{3}{|c|}{ Tuntas } & \multicolumn{3}{|c|}{ Tuntas } \\
\hline
\end{tabular}

Keterangan:

$\mathrm{F}=$ Frekuensi

$\mathrm{P}=$ Persentase

$\mathrm{B}=$ Bobot/jumlah skor

Selain pengetahuan, keterampilan membaca teks klasifikasi peserta didik kelas X-MIPA SMA Negeri 1 Gunungsitoli Idanoi mengalami peningkatan setelah mengikuti pembelajaran membaca teks klasifikasi menggunakan metode SQ3R dengan media gambar. Pada siklus I, nilai rata-rata penilaian keterampilan mencapai 82 dengan persentase ketuntasan $57 \%$. Sementara pada siklus II nilai rata-rata meningkat signifikan menjadi 93. Persentase ketuntasan pada siklus II juga meningkat secara tajam menjadi $100 \%$. Dengan demikian, keterampilan peserta didik mengalami peningkatan dari siklus I ke siklus II. Berikut tabel yang mendeskripsikan peningkatan hasil tes keterampilan membaca teks klasifikasi menggunakan metode SQ3R dengan media gambar pada peserta didik kelas X-MIPA SMA Negeri 1 Gunungsitoli Idanoi.

Tabel 5 Hasil Tes Keterampilan Membaca Teks Klasifikasi Siklus I dan II

\begin{tabular}{|c|c|c|c|c|c|c|c|}
\hline \multirow{2}{*}{ No } & \multirow{2}{*}{ Skor } & \multicolumn{3}{|c|}{ Siklus I } & \multicolumn{3}{c|}{ Siklus II } \\
\cline { 3 - 8 } & & F & P & B & F & P & B \\
\hline 1 & $90-100$ & 4 & $17 \%$ & 470 & 22 & $92 \%$ & 1945 \\
\hline 2 & $70-89$ & 10 & $43 \%$ & 1285 & 2 & $8 \%$ & 255 \\
\hline 3 & $50-69$ & 9 & $40 \%$ & 105 & 0 & $0 \%$ & 0 \\
\hline 4 & $20-49$ & 0 & $0 \%$ & 0 & 0 & $0 \%$ & 0 \\
\hline 5 & $0-19$ & 0 & $0 \%$ & 0 & 0 & $0 \%$ & 0 \\
\hline Jumlah & 23 & $100 \%$ & 1860 & 24 & $100 \%$ & 2200 \\
\hline Rerata & \multicolumn{3}{|c|}{1860} & 23 & 81 & \multicolumn{3}{c|}{2200} & 24 \\
\hline Ketuntasan & \multicolumn{3}{|c|}{$\frac{14}{23} \times 100 \%=61 \%$} & $\frac{24}{24} \times 100 \%=100 \%$ \\
\hline Ket & \multicolumn{3}{|c|}{ Tuntas } & \multicolumn{3}{c|}{ Tuntas } \\
\hline
\end{tabular}

Keterangan:

$\mathrm{F}=$ Frekuensi

$\mathrm{P}=$ Persentase

$\mathrm{B}=$ Bobot/jumlah skor

Tanggapan peserta didik terhadap pembelajaran membaca teks klasifikasi menggunakan metode SQ3R dengan media gambar sangat baik. Berdasarkan hasil jurnal dan wawancara, peserta didik tampak puas dengan pembelajaran ini. Mereka merasakan kemudahan, kenyamanan, dan keberhasilan dalam pembelajaran membaca teks klasifikasi menggunakan metode SQ3R dengan media gambar. Kesan peserta didik pada pembelajaran ini dari siklus I dan siklus II juga sangat positif. Dengan demikian, pembelajaran membaca teks 
klasifikasi menggunakan metode SQ3R dengan media gambar dapat diterima secara positif oleh peserta didik kelas X-MIPA SMA Negeri 1 Gunungsitoli Idanoi.

Tanggapan guru sebagai kolaborator terhadap pembelajaran membaca teks klasifikasi menggunakan metode SQ3R dengan media gambar sangat baik. Hasil jurnal guru menunjukkan respon positif dari guru sebagai kolaborator dalam penelitian ini. Guru menilai penelitian ini berhasil. Menurut guru juga tampak perbandingan yang positif antara siklus I dan siklus II. Peserta didik yang semula masih bingung dengan metode baru dalampembelajaran, mulai aktif, kondusif, dan interaktif dalam siklus II. Berdasarkan hasil jurnal guru, guru tampak mendukung dan senang dengan penelitian ini. Dengan demikian, pembelajaran membaca teks klasifikasi menggunakan metode SQ3R dengan media gambar mendapatkan respon positif dari guru mata pelajaran bahasa Indonesia pada kelas X-MIPA SMA Negeri 1 Gunungsitoli Idanoi.

\section{Simpulan}

Berdasarkan data, analisis, dan pembahasan dalam penelitian ini yang telah diuraikan pada bagian sebelumnya, penulis mengambil simpulan bahwa terjasi peningkatan 1) Keberlangsungan proses pembelajaran membaca teks klasifikasi pada peserta didik kelas X-MIPA SMA Negeri 1 Gunungsitoli Idanoi semakin baik. 2) Sikap religius peserta didik kelas $X$ MIPA SMA Negeri 1 Gunungsitoli Idanoi mengalami peningkatan setelah mengikuti pembelajaran membaca teks klasifikasi menggunakan metode SQ3R dengan media gambar. 3) Sikap sosial peserta didik kelas X-MIPA SMA Negeri 1 Gunungsitoli Idanoi mengalami peningkatan setelah mengikuti pembelajaran membaca teks klasifikasi menggunakan metode SQ3R dengan media gambar. 4) Pengetahuan membaca teks klasifikasi peserta didik kelas X-MIPA SMA Negeri 1 Gunungsitoli Idanoi mengalami peningkatan dan dapat memenuhi target ketuntasan yang diharapkan, dan 5) Keterampilan membaca teks klasifikasi peserta didik kelas X-MIPA SMA Negeri 1 Gunungsitoli Idanoi mengalami peningkatan setelah mengikuti pembelajaran membaca teks klasifikasi menggunakan metode SQ3R dengan media gambar.

\section{Daftar Pustaka}

[1] Adipta, H., dkk. (2016). "Pemanfaatan Buku Cerita Bergambar Sebagai Sumber Bacaan Siswa SD". Jurnal Pendidikan: Teori Penelitian Dan Pengembangan,1(5): 989-992.

[2] Agustina, R. \& Hariyadi, H. (2018). Penerapan Metode SQ3R dan Metode PQ3R terhadap Keterampilan Membaca pada Mahasiswa. AKSIS: Jurnal Pendidikan Bahasa dan Sastra Indonesia, 2(1), 69-80, doi:10.21009/aksis.020105

[3] Anwar, K. (2012). Kemampuan Membaca Pemahaman dalam Pengembangan Anak. Jurnal Pendidikan Dasar, 3(5): 212-216

[4] Arikunto, Suharsimi. Dkk. (2015). Penelitian Tindakan Kelas Jakarta: Bumi Aksara

[5] Armitasari, A. M. (2015). Peningkatan Membaca Permulaan dengan Menggunakan Media Kartu Kata Bergambar Pada Siswa Kelas I SD. Jurnal Pendidikan Guru Sekolah Dasar, 37(5): 2.483-2.484.

[6] Dalman, H. (2014). Keterampilan Membaca. Jakarta : RajaGrafindo

[7] Ilmi, D. N., Hermawan, R., \& Riyadi, A. R. (2017). Metode Pembelajaran Sq3R Untuk Meningkatkan Kemampuan Membaca Pemahaman. Jurnal Pendidikan Guru Sekolah Dasar, 2(4), 88-99. https://doi.org/10.17509/jpgsd.v2i4.1 4009 
[8] Karmawan, G. Y. dkk. (2016). Penerapan Metode Pembelajaran SQ3R untuk Meningkatkan Keaktifan dan Keterampilan Membaca Siswa Kelas IV SD. E-Journal PGSD Universitas Pendidikan Ganesha, Vol .4 (1): 1-10.

[9] Rahman, I. F. (2014). Meningkatkan Kemampuan Membaca Kata Melalui Media Flash Card Untuk Anak Kesulitan Belajar. Jurnal Ilmiah Pendidikan Khusus, 3(3); 438 - 445.

[10] Sobri. (2017). Strategi Belajar Sq3r (Survey, Question, Read, Recite, Review) dalam Upaya Peningkatan Pemahaman Bacaan Siswa. Journal of Language Learning and Research (JOLLAR), 1(1), 57-75. https://doi.org/10.22236/JOLLAR

[11] Usman, R. (2015). Penggunaan Metode Sq3R Dan Motivasi Belajar Terhadap Hasil Belajar Membaca
Pemahamaman Siswa Kelas Xi Sma Negeri 12 Pekanbaru. Primary: Jurnal Pendidikan Guru Sekolah Dasar, $\quad 4(2), \quad 105$. https://doi.org/10.33578/jpfkip.v4i2.2 $\underline{944}$

[12] Zuhri, D. (2012). Strategi Meningkatkan Kemampuan Membaca, Peningkatan Komprehensi. Yogyakarta: UNY Press.

\section{Profil Penulis}

Trisman Harefa, S.S., M.Pd. adalah dosen tetap di Yayasan Perguruan Tinggi Nias. Beliau mengajar di FPBS Prodi Pendidikan Bahasa Indonesia, IKIP Gunungsitoli. Penulis Lulus S1 pada tahun 2011 di Prodi Sastra Inggris Universitas Sisingamangaraja XII Tapanuli Utara dan Lulus S2 pada tahun 2014 di Prodi Pendidikan Bahasa Inggris Universitas HKBP Nommensen. 